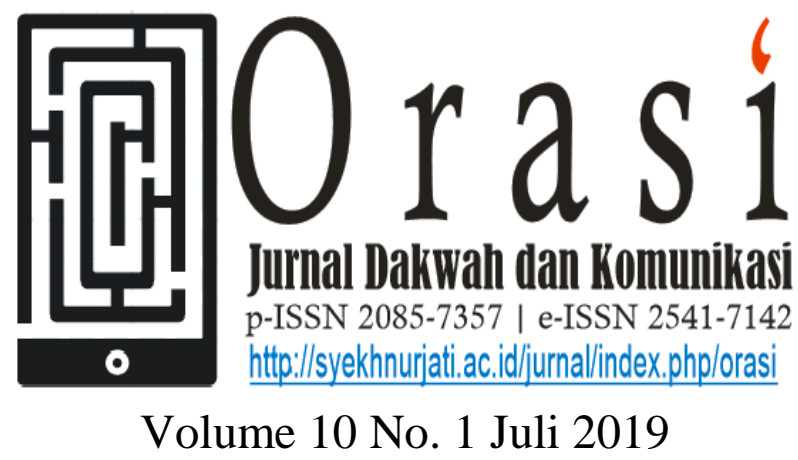

\title{
DAKWAH SEBAGAI MEDIA KONSELING SPIRITUAL
}

\author{
M. Fuad Anwar \\ Fakultas Ushuluddin Adab dan Dakwah IAIN Syekh Nurjati Cirebon \\ Jl. Perjuangan By Pass Sunyaragi Cirebon \\ e-mail: fuad.anwar@syekhnurjati.ac.id
}

\begin{abstract}
Da'wah is one of the spiritual counseling media that has a strategic role in forming a Muslim identity and self-concept. In da'wah, there are many revelations from Allah SWT. and the Prophet's traditions about how people should behave and live in the world. The Qur'an contains a lot of meaning and guidance about life, that someone in the life of the world always follows what is required by Allah SWT, will receive a reward of heaven, whereas if many people deny what Allah commands, then he will go to hell. Da'wah is an activity that is very urgent in Islamic religion, to disseminate information about religion. Spirituality and religion are humanities that cannot be separated from old culture and are important for many people of all time. The same terminology as spiritual centered counseling is religious, humanistic and transpersonal.
\end{abstract}

Keywords: Counseling, Da'wah, Spiritual.

\section{ABSTRAK}

Dakwah salah satu media konseling spiritual yang memiliki peran strategis dalam pembentukan identitas diri dan konsep diri seorang muslim. Dalam dakwah, tersirat banyak wahyu-wahyu Allah Swt. dan hadist-hadis Nabi SAW tentang bagaimana orang seharusnya berperilaku dan hidup di dunia. Al-Qur'an mengandung banyak makna dan tuntunan tentang hidup, bahwa seseorang dalam kehidupan dunia selalu mengikuti apa yang diwajibkan Allah SWT., akan mendapat balasan surga, sedangkan jika orang banyak mengingkari apa yang diperintahkan Allah SWT., maka ia akan masuk neraka. Dakwah merupakan aktivitas yang sangat urgen didalam agama islam, untuk menyebarkan informasi tentang keagamaan. Spiritual dan agama merupakan humanity yang tidak dapat dipisahkan dari kebudayaan lama dan merupakan hal penting bagi 
banyak orang sepanjang masa. Terminologi yang sama dengan konseling yang berpusat spiritual adalah agama, humanistik dan transpersonal.

Kata Kunci: Dakwah, Konseling, Spiritual.

\section{Pendahuluan}

Ada beberapa teori dan pendekatan konseling yang menjadi landasan oleh para konselor dalam membantu klien menghadapi masalah. Menurut Corey (2011) ada sembilan aliran, salah satunya adalah teori Eksistensial Humanistik, memuat tentang enam dimensi dasar positif yang dimiliki oleh setiap manusia, yaitu:

1. Kapasitas akan kesadaran diri;

2. Kebebasan serta tanggung jawab;

3. Menciptakan identitas dirinya dan menciptakan hubungan yang bermakna dengan orang lain;

4. Usaha pencarian makna, tujuan, nilai dan sasaran;

5. Kecemasan sebagai suatu kondisi hidup;

6. Kesadaran akan datangnya maut serta ketidakberadaan.

Dalam sumber ajaran Islam yang terdapat dalam Al Qur'an dan Hadist, sebenarnya sudah banyak ayat-ayat yang mengandung arti konseling, hanya saja masih tersebar di berbagai tempat dan belum tersusun secara sistematis dan dipilah-pilah seperti dalam konseling secara umum. Terutama dalam sistematika tentang : hakikat manusia, pribadi sehat, pribadi tidak sehat, konsep konseling, peran dan fungsi konselor serta tehnik dan prosedur dalam konseling. Oleh karena itu, kiranya tidak terlalu berlebihan apabila penelitian ini bertujuan untuk mencari bahan dari Islam, khususnya ayat-ayat yang memiliki dan mengandung nilai konseling.

Demikian pula halnya dalam proses konseling, karena mayoritas masyarakat Indonesia beragama Islam maka diupayakan mencari bentuk konseling yang sesuai dengan kondisi masyarakat Indonesia tersebut, tanpa menutup kemungkinan diberlakukannya konseling non Islam. Teori Eksistensial Humanistik memuat tentang enam dimensi dasar positif yang menurut penulis berdekatan dengan Islam. Karena apa yang terkandung di dalamnya terdapat juga dalam ajaran Islam. Oleh karena itu dalam penelitian ini penulis ingin mencoba mengungkap lebih mendalam lagi tentang materi enam dimensi dasar positif tersebut dikaitkan dengan konseling Islam dalam mengembangkan kepribadian islami.

Islam memang benar-benar menyuruh kita untuk mengenal diri kita masing-masing. Menyelami kepribadian kita dan benar-benar mengerti watak dan karakter diri kita, sebagaimana juga dengan diri orang lain, yang mana semua itu hanya semata agar kita akan mengenal siapa Pencipta dari itu semua.

Untuk memahami dan menjelaskan tingkah laku kita sendiri dan orang lain, kita membutuhkan kerangka acuan. Sebagai seorang muslim, tentu saja kerangka acuan yang digunakan juga haruslah yang mencerminkan segi-segi Islami. Untuk menyusun teori-teori kepribadian yang berwawasan Islam, kita harus tetap memakai dan juga menguasai ilmu pengetahuan masa kini dan juga mampu merekonstruksikan ilmu-ilmu itu sehingga menjadi suatu yang selaras dengan wawasan dan ideal-ideal Islam.

Dalam sejarah agama kita saksikan manusia berusaha mencari perlindungan dalam agama tertentu untuk mencari ketentraman jiwa, yaitu suatu usaha untuk memperbaiki kesehatan mentalnya. Kesehatan mental dapat dicapai antara lain dengan cara meyakini akan ajaran agama, keteguhan dalam mengindahkan normanorma sosial, hukum, moral dan sebagainya. Hal yang menentukan ketenangan dan

Orasi: Jurnal Dakwah dan Komunikasi | Volume 10, No. 1, Juli 2019 
kebahagiaan hidup adalah kesehatan mental. Orang yang sehat mentalnya tidak akan lekas merasa putus asa, pesimis, apatis, karena ia dapat menghadapi semua rintangan/ kegagalan dalam hidup dengan tenang dan wajar serta menerima kegagalan itu sebagai suatu pelajaran yang akan membawanya menuju kesuksesan nanti.

Menurut Al Qur'an dalam surat Ar rum 30:30 bahwa kerisauan - kerisauan itu bersumber dati keadaan-keadaan manusia sendiri, yaitu mempunyai sifat suka lupa. Sehingga perlu ditingkatkan melalui bimbingan, pembinaan dan pembiasaan untuk mewujudkan potensi-potensi intelektualnya,keiihlasan pada diri sendiri dan nilai- nilai spiritual manusia. Bagi kita sebagai makhluk yang beragama, kebutuhan ruhani, spiritual ini dapat diperoleh lewat bimbingan agama. Agama merupakan kebutuhan dasar spiritual manusia. ( Surah Ar Ruum, $30: 30$ ).

\section{Konsep Dasar Konseling Spiritual}

Spiritualitas berasal dari bahasa latin "spiritus" yang memiliki arti "breath of life" atau dalam terjemahan bahasa Indonesia disebut dengan nafas kehidupan, sehingga dapat diartikan juga menghidupkan kekuatan hidup, yang direpresentasikan melalui berbagai citra, seperti: nafas, angin, kekuatan, dan keberanian (Miller, 2003: 6). Seiring dengan pendapat tersebut, Lines (2006: 34) menyatakan bahwa spirit berasal dari bahasa Latin "spiritus" yang berarti nafas (breath). Istilah spirit merupakan agency supernatural yang beroperasi di alam atau dalam kehidupan manusia. Spirit sering disebut transpersonal, atau spirit merupakan medium yang menghubungkan manusia dengan Sang Maha "Transenden”. Spirit juga merupakan Idea dari Sang Transenden tersebut. Idea berada "diluar sana" yang bersifat lebih tinggi daripada makhluk yang ada "disini” yang padaNya kita bergantung.
Lebih lanjut lagi Miller (2003: 6) menyatakan bahwa spiritualitas adalah menghilang atau masuknya spirit dalam kehidupan seorang manusia, yang dialami sebagai proses yang aktif maupun pasif. Spiritualitas juga diartikan sebagai kapasitas atau tendensi yang dimiliki setiap orang dan bersifat unik. Tendensi spiritual tersebut menggerakkan individu ke arah pengetahuan, kebermaknaan, kecintaan, harapan, kedamaian, transendensi, keterhubungan, keterharuan, kebaikan dan ketulusan hati. Kapasitas seseorang dalam kreativitas, pertumbuhan dan perkembangan sistem nilai merupakan bagian dari spiritualitas. Bilamana dilihat melalui pendekatan berbagai perspektif, meliputi psikospiritual, religius dan transpersonal, spiritualitas biasanya terekspresi melalui budaya, baik budaya terdahulu maupun transenden.

Syamsu Yusuf (2009: 6) menyatakan bahwa spiritualitas dapat dipahami dari berbagai persfektif, yaitu:

a. Proses personal dan sosial yang merujuk kepada gagasan, konsep, sikap dan tingkah laku yang berasal dari individu sendiri.

b. Pengalaman intra, inter, dan transpersonal yang dibentuk dan diarahkan oleh pengalaman individu itu hidup.

c. Kesadaran transedental yang ditandai dengan nilai-nilai tertentu, baik yang terkait dengan diri sendiri, orang lain, alam, kehidupan, dan segala sesuatu yang dipandang menjadi tujuan akhir.

d. Kapasitas dan kecenderungan yang bersifat unik dan bawaan dari semua orang.

e. Aktivitas manusia yang mencoba untuk mengekspresikan pengalamanpengalamannya yang mendalam dan bermakna bagi dirinya sendiri.

f. Kecerdasan ketuhanan (divine intelligence) yang membangun keharmonisan dengan Tuhan dan alam. 
Wilber (dalam Burke, 2005: 4) menyatakan bahwa spiritualitas melibatkan tingkat tertinggi dari garis perkembangan, jumlah total dari garis perkembangan ialah sebuah garis perkembangan terpisah, sebuah sikap (seperti keterbukaan atau cinta) bahwa Anda dapat mencapai apa pun tingkatan anda, pada dasarnya melibatkan pengalaman puncak. Lebih lanjut lagi Lines (2006: 2) menyatakan bahwa konseling spiritual merupakan suatu cara untuk berinteraksi antara praktisi konseling dengan mengesampingkan cara lama agar terlibat dalam proses terapi antar manusia, untuk merespon kliennya dengan keterlibatan timbal balik, sehingga keduanya seolah-olah sedang dalam pengembaraan diri transendens secara terus menerus dengan memberdayakan dirinya secara individual sebagai manusia.

Konseling spiritual yang berorientasi ketuhanan disebut oleh Yusuf (2010: 7) sebagai konseling spiritual teistik, yaitu proses pemberian bantuan kepada individu agar memiliki kemampuan untuk mengembangkan fitrahnya sebagai makhluk beragama, berperilaku sesuai dengan nilainilai agama (berakhlak mulia) dan mengatasi masalah-masalah kehidupan melalui pemahaman, keyakinan dan praktik-praktik ibadah ritual agama yang dianutnya.

Tujuan umum konseling spiritual atau keagamaan adalah untuk memberikan fasilitas dan meningkatkan kemampuan klien dalam mengembangkan kesadaran beragama atau spiritualitasnya dan mengatasi berbagai masalah yang dihadapinya sehingga dapat mencapai kehidupan yang bermakna (Yusuf, 2010: 36-39).

Karena teknik konseling religius dapat diadaptasi untuk konseling/terapi spiritual sekuler, maka Lines (2006: 27) menyebutkan beberapa teknik yang dapat digunakan dalam konseling religius dan pastoral sesuai dengan hasil kesimpulan Richard dan Bergin (1997: 172), "teknik dan intervensi yang seringkali dipakai oleh agama secara tradisi di dunia adalah: berdo'a, membaca kitab suci, pemberian maaf dan meditasi".

Membaca Kitab Suci merupakan kegiatan yang cukup penting dalam konseling religius ataupun spiritual, sebagaimana diungkapkan oleh Lines (2006: 160) membaca kitab atau tulisan suci secara rutin dipandang sebagai pendekatan yang tepat dalam proses konseling spiritual, baik sebagai media dalam penanaman nilai spiritual maupun sebagai sumber bahan belajar tentang bagaimana hidup. Teks spiritual memiliki kearifan spiritual dan moral yang kaya, meskipun tidak semua tulisan keagamaan diklaim sebagai wahyu dari Tuhan ataupun dewa-dewa.

Teknik perlakuan spesifik untuk mengembangkan kehidupan spiritual/religius seorang klien yang dapat digunakan sebagai pengembangan kemampuan dan sumberdayanya dalam mengakses ranah spiritual menurut Miller (2003: 194) terbagi menjadi tiga, yaitu: praktek religius, praktek umum, serta praktek religius-umum. Praktek religius terdiri dari berdo'a; membaca kitab/tulisan suci; serta komunitas religius. Praktek umum terdiri dari biblioterapi, fokus dan menulis jurnal. Praktek religius dan umum, terdiri dari meditasi/relaksasi/ pembayangan; dan ritual.

Penggunaan kitab/tulisan suci atau biblioterapi religius termasuk salah satu teknik konseling spiritual/religius. Miller (2003: 196) meyakini bahwa penggunaan kitab suci akan membantu klien untuk dapat merubah keyakinannya, melihat masalah dengbern sudut pandang yang berbeda dan memahami kitab suci dengan lebih baik, serta mencari kekuatan yang lebih tinggi. Cerita yang ada dalam kitab suci akan mengajarkan kepada kita bagaimana cara hidup. Kekuatan pembacaan kitab suci menurut Allan dan Garret (1998: ) adalah pada pengalaman subyektif pendengar tentang kisah yang dibacanya, dan pada apa yang didengar serta 
pada apa makna yang dipahami klien dari kisah tersebut. Konselor dapat membantu klien dengan cara terlibat dalam diskusi tentang makna bacaan bagi klien dan membantu klien menerapkan bacaan tersebut untuk pengobatannya.

Berdasarkan berbagai pendapat tersebut, dapat disimpulkan bahwa bimbingan dan konseling spiritual merupakan proses interaksi dalam konseling yang dilakukan untuk mendalami, memahami, menyadari dan merasakan bahwa manusia sebagai individu tidak dapat terlepas dari keberadaan Tuhan, sehingga manusia sebagai individu harus mampu menjalankan nilai-nilai dan aturan yang Tuhan percayakan kepada manusia. Dalam hal ini, pembentukan konsep diri manusia dalam konteks bimbingan dan konseling spiritual dapat dilakukan dengan cara berdo'a, membaca kitab suci, meditasi/muhasabah untuk memohon pengampunan, keberkahan, kekuatan dan perlindungan dari Tuhan.

Lain halnya dengan Arifin (2009:

44) menjelaskan keistimewaan teknik diagnostik berbasis Al-Qur'an bahwa “AlQur'an memuat prinsip-prinsip dasar elemen psikologi yang kemudian dikembangkan menjadi psikologi kepribadian menurut AlQur'an”. Menurut Madjedi Hasan (Husen, 2010: iii) “Al Qur'an dapat memberi pencerahan dan mampu memberikan motivasi bagi umat dalam kehidupan ini dalam menghadapi persoalan”. Demikian pula menurut Lines (2006: 160): "Reading scripture has regularly been viewed as appropriate in religious counseling, both for spiritual edification and as a source of teaching on how to live. Religious texts have a rich store of spiritual and moral wisdom." Membaca kitab suci secara rutin dipandang tepat dalam proses konseling religius, baik untuk peneguhan rohani dan sebagai sumber pengajaran tentang bagaimana hidup. Teksteks agama memiliki kekayaan kebijaksanaan spiritual dan moral.

\section{Landasan Teologis}

Konseling spiritual berlandaskan kepada pandangan tentang Tuhan, hakekat manusia, tujuan hidup, spiritualitas, moralitas, dan hidup setelah mati.

a. Pandangan tentang Tuhan

Muslim meyakini Allah SWT sebagai Tuhan yang menciptakan manusia dan alam semesta, Allah Maha Kasih Sayang, Maha Mengetahui, Maha Mendengar, dan Kekal. Allah telah menurunkan wahyu-Nya kepada Nabi Muhammad SAW, dalam wujud kitab suci Al-Qur'an.

b. Pandangan tentang hakikat manusia

Di dalam memahami hakekat manusia menurut perspektif Islam, haruslah dilihat dari sumber utamanya yaitu AlQur'an. Dalam Al-Qur'an diuraikan bagaimana Allah telah menciptakan manusia dari materi dan roh, dengan melewati beberapa fase penciptaan sebagaimana Allah SWT berfirman dalam QS. Shad (38: 71-72).

$$
\text { (ingatlah) ketika Tuhanmu }
$$

berfirman kepada malaikat, "Sesungguhnya aku akan menciptakan manusia dari tanah, kemudian apabila telah sempurnakan kejadiannya dan kutiupkan roh (ciptaan) $\mathrm{Ku}$ kepadanya, maka tunduklah kamu dengan bersujud kepadanya.

Allah SWT juga berfirman dalam QS. Al Hijr (15: 28-29).

"Dan (ingatlah), ketika Tuhanmu berfirman kepada para malaikat, sesungguhnya aku akan menciptakan manusia dari tanah liat kering (yang berasal) dari lumpur hitam yang diberi bentuk, maka apabila aku telah menyempurnakan kejadiannya, dan telah kutiupkan ke dalamnya roh (ciptaan) Ku, maka tundukkanlah kamu kepadanya dengan bersujud."

c. Pandangan tentang tujuan hidup

Tujuan hidup seorang muslim adalah untuk memperoleh ridho Allah SWT, 
dengan cara melakukan tugas dan kewajibannya di dunia ini, yaitu untuk beribadah kepada Allah, melalui habluminallah dan habluminannas.

d. Pandangan tentang spiritualitas

Ketaatan tentang hukum-hukum Allah yang tertulis dalam kitab suci AlQur'an telah mengembangkan spiritualitas setiap muslim. Spiritualitas yang dimiliki seorang muslim dapat mencegah dirinya dari berbagai perbuatan tercela seperti arogensi, tamak, dan tidak jujur. Nilai spiritual seorang muslim diperoleh melalui pengalaman ibadah mahdlah, yaitu dengan cara berkomunikasi langsung dengan Allah, seperti sholat, berdoa atau berdzikir, serta melafalkan kalimah toyyibah.

e. Pandangan tentang moralitas

Allah SWT telah menurunkan hukum-hukumnya dalam Al-Qur'an. Orang yang baik adalah yang menaati hukumhukum, dan beribadah kepada-Nya. Ada lima klasifikasi tentang tindakan moral, yaitu wajib, sunnah, makruh, haram dan mubah. Contoh tindakan moral yang buruk atau yang diharamkan adalah meminum minuman beralkohol, berjudi dan berzina. Sementara contoh tindakan moral yang baik atau yang diwajibkan adalah seperti sholat, zakat dan puasa.

f. Pandangan tentang hari akhir (akhirat)

Salah satu rukun iman dan rukun islam adalah beriman kepada hari akhir. Hari akhir adalah hari pengadilan, pertanggungjawaban setiap jawaban di dunia. Orang yang beramal baik akan dibalas dengan syurga dan yang beramal buruk akan dibalas dengan neraka.

Spiritual dan agama merupakan humanity yang tidak dapat dipisahkan dari kebudayaan lama dan merupakan hal penting bagi banyak orang sepanjang masa. Terminologi yang sama dengan konseling yang berpusat spiritual adalah agama, humanistik dan transpersonal (Lines, 2006: 4). Dimensi spiritual bukanlah hal yang asing dalam agama-agama di dunia, Johar (2000: xxiii) menyatakan bahwa "William James, yang dalam beberapa hal mempengaruhi pemikiran Jung, mengembangkan psikologi transpersonal-nya bersama Maslow dan berusaha menggabungkan tradisi psikologis dengan tradisi agama-agama besar di dunia. Sepanjang zaman manusia bertanya 'siapakah aku?', tradisi keagamaan menjawabnya dengan menukik jauh kedalam 'wujud spiritual, ruh'. Praktek-praktek keagamaan mengajarkan kita untuk menyambungkan diri kita dengan bagian diri kita yang terdalam ini."

Konseling yang mengintegrasikan nilai-nilai spiritual sudah banyak diminati. Baik konselor maupun konseli telah menyadari pengaruh dan manfaat nilai-nilai yang berasal dari agama atau kepercayaan spiritual bagi kehidupan individu.

Menurut Syamsu Yusuf (2010: 1-3)

akhir abad 20 ditandai dengan berkembangnya minat terhadap isu-isu spiritual dan keyakinan (keimanan) di Amerika Serikat. Berbagai majalah dan koran terkemuka, seperti Time, Newsweek, U.S. News, dan World Report memuat pemberitaan atau artikel-artikel tentang isuisu tersebut. Beratus-ratus buku popular dan banyak stasiun televisi yang menaruh perhatian untuk membahas atau menayangkan isu-isu spiritual dan keagamaan. Beribu-ribu Web Site tentang spiritualitas dan agama telah diciptakan. Berbagai organisasi dan lembaga penelitian telah melakukan studi tentang keyakinan dan spiritualitas ini. Jutaan warga masyarakat Amerika mencari pemahaman yang benar tentang bagaimana keyakinan dan spiritualitas itu dapat membantu mereka dalam menjalani kehidupannya sehari-hari. Banyak ahli psikoterapi/konseling yang tidak memiliki persiapan atau pemahaman dan keterampilan untuk menangani isu-isu spiritual, ditambah lagi bahwa mereka memiliki pandangan sekuler, atau kurang 
mengalami kehidupan beragama, sehingga mereka mengalami hambatan dalam membantu klien.

Organisasi Amnesti Internasional Interfaith Network untuk Hak Azasi Manusia menyatakan bahwa perhatian terhadap spiritual dan religius merupakan perhatian internasional. Perkembangan di bidang spiritual dan agama ini, membutuhkan persiapan bagi para konselor ketika mereka dihadapkan pada klien yang menginginkan perhatian spiritual atau religius untuk mengembangkan ketahanan dan kesehatan mental mereka (Miller, 2003: 1).

Sejarah psikoterapi/treatment medis adalah pemahaman dan penyembuhan penyakit mental berlandaskan makna religius yang telah mengalami transisi. Diagnosa medis ilmiah mengambil alih catatan layanan dari agama selama berabad-abad lamanya. Dengan alasan rasional untuk memperoleh manfaat dan agar mampu mandiri serta bebas dari ketergantungan dalam lingkungan masyarakat, program treatmen untuk mengurangi penyakit mental dilakukan dalam ruang konsultasi antara dokter dengan pasiennya melalui pembicaraan tentang penyembuhan pikiran dengan menggunakan pikiran (Lines, 2006: 44).

\section{Dakwah Sebagai Media Implementaasi Konseling Spiritual Islam}

Dakwah menjadi salah satu media bimbingan dan konseling spiritual yang memiliki peran strategis dalam pembentukan konsep diri bagi seorang muslim. Dalam dakwah, tersirat banyak wahyu-wahyu Allah SWT dan Sunnah Rasul tentang bagaimana orang seharusnya berperilaku dan hidup di dunia ini. Lebih mendalam lagi, ayat-ayat dalam Al-Qur'an mengandung banyak makna dan tuntunan tentang cara menjalani kehidupan, bahwa orang yang dalam kehidupan dunia selalu mengikuti apa yang diperintahkan Allah SWT, akan mendapat balasan surga, sedangkan jika orang banyak mengingkari apa yang diperintahkan Allah SWT, maka ia akan masuk ke dalam neraka.

Dakwah merupakan aktivitas yang sangat penting di dalam agama Islam, yang berfungsi untuk menyebarkan informasi tentang keagamaan. Menurut bahasa dakwah berarti ajakan, seruan, undangan dan panggilan sedangkan menurut istilah, dakwah berarti menyeru untuk mengikuti sesuatu dengan cara dan tujuan tertentu (Kusnawan, 2004: 7). Di mana tujuan dakwah dalam penelitian ini adalah pembentukan konsep diri berdasarkan nilai-nilai spiritual, Ali Aziz (2004: 4-5) menguraikan beberapa pendapat tentang dakwah:

a. Syekh Ali Makhfud dalam kitabnya Hidayatul Mursyidin, Dakwah adalah mendorong manusia untuk berbuat kebajikan dan mengikuti petunjuk (agama), menyeru mereka kepada kebaikan dan mencegah mereka dari perbuatan munkar agar memperoleh kebahagiaan dunia dan akhirat.

b. Toha Yahya Oemar berpendapat bahwa dakwah adalah mengajak manusia dengan cara bijak sana kepada jalan yang benar sesuai dengan perintah tuhan untuk kemaslahatan dan kebahagiaan mereka di dunia dan akhirat.

c. Nasrudin Latif mendefinisikan dakwah adalah setiap usaha aktifitas dengan lisan maupun tulisan yang bersifat mengajak, menyeru, memanggil manusia lainnya untuk beriman dan menaati Allah Swt., sesuai dengan garigaris akidah dan syariat serta akhlak islaminya. Selain itu masih banyak lagi pendapat tentang definisi dakwah.

Berdasarkan berbagai definisi dakwah di atas, dapat disimpulkan bahwa dakwah mencerminkan hal-hal sebagai berikut: pertama, dakwah adalah suatu usaha atau proses yang diselenggarakan secara 
sadar dan terencana. Kedua usaha yang dilakukan adalah mengajak umat manusia menuju jalan Allah, untuk memperbaiki situasi menjadi lebih baik (dakwah bersifat pembinaan dan pembangunan). Ketiga, Usaha tersebut dilakukan dalam rangka mencapai tujuan tertentu, yakni hidup bahagia, sejahtera baik di dunia maupun di akhirat (Syukir, 1983: 21).

Dakwah merupakan salah satu bentuk aktivitas keagamaan yang secara langsung digunakan untuk mensosialisasikan ajaran agama Islam bagi penganutnya dan umat manusia pada umumnya. Aktifitas ini baik dilakukan secara lisan, tulisan, maupun perbuatan nyata (dakwah bi al- lisan, wa bi al-qalam, wa bi al-hal).

Secara kualitatif dakwah bertujuan untuk mempengaruhi dan mentransformasikan sikap batin dan perilaku khalayak menuju suatu tatanan kesalehan individu dan kesalehan sosial. Dakwah dengan pesan-pesan keagamaannya dan pesan-pesan sosialnya merupakan ajakan kepada kesadaran untuk senantiasa memiliki komitmen (istiqomah) di jalan yang lurus.

Dakwah hadir sebagai solusi bagi persoalan-persoalan yang dihadapi umat, karena di dalamnya penuh dengan nasehat, pesan keagamaan dan sosial, serta keteladanan untuk menghindari dari hal-hal negatif menuju hal-hal positif yang di ridhoi Allah SWT. Disamping itu juga, dakwah harus dapat menampilkan Islam sebagai ikon rahmat semesta (rahmat lil alamin). Bukan saja pada aspek pandangan hidup bagi umat islam, akan tetapi juga untuk umat lainnya sebagai keuniversalannya. Dengan demikian dakwah berfungsi sebagai sarana pemecahan permasalahan yang terjdi di kehidupan manusia, karena dakwah merupakan sarana penyampaian informasi ajaran Islam, yang di dalamnya mengandung dan befungsi sebagai edukasi, kritik dan kontrol sosial (Munir dan Ilaihi, 2006: 1-3).
Najati (2005: 352) menyatakan bahwa dengan membaca Al-Qur'an (Kitab suci bagi umat Islam) akan membuat dosadosa kita terampuni, menggandakan kebaikan, dan meneguhkan harapan akan masuk surga. Karena itu membaca al Qur'an merupakan terapi untuk menghilangkan kegelisahan yang timbul akibat perasaan berdosa. Ibnu Taimiyyah mengemukakan: "Al Qur'an adalah obat untuk setiap penyakit yang ada di dalam dada serta bagi orangorang yang di dalam hatinya terdapat penyakit ragu dan syahwat. Al Qur'an mengandung bermacam penjelasan yang bisa memilah yang hak dari yang batil".

$$
\text { Makhdlori (2007: }
$$

mengungkapkan sesuatu yang "magis" atau mistik, daya spiritual tertinggi dalam arti metafisis tentang isi Al-Qur'an: Ayatayatnya menyerupai azimat yang melindungi manusia yang tengah mengetahui rahasia didalamnya. Kehadiran fisis Al-Qur'an membawa keberkahan bagi manusia yang mempercayainya. Apabila seseorang menghadapi kesulitan hidup, kegoncangan jiwa seperti stres, depresi, sindrom, maka akan sembuh dengan kekuatan "magis" spiritual yang ada dalam ayat-ayat tertentu dengan kekuatan suci dari alam transendens. Firman Allah dalam surat Al-A'raf Ayat 204, yang artinya: "Dan apabila dibacakan AlQur'an, maka dengarkanlah baik-baik dan perhatikanlah dengan tenang agar kamu sekalian mendapat rahmat-Nya”. Al Qur'an adalah sumber hukum yang mengatur kehidupan manusia sehari-hari dan sumber pengetahuan bagi kegiatan intelektual manusia, baik yang bersifat material maupun nonmaterial.

Do'a mengandung banyak manfaat. Miller (2003: 192) menjelaskan manfaat berdo'a, antara lain membuat orang mendekatkan diri pada Yang Maha Suci baik dalam cara bertindak, berpikir maupun sikap. Berdo'a adalah berbicara, dan orang akan mengurangi kesibukan hidup serta 
menemukan informasi tentang jawabanjawaban atas segala pertanyaan mengenai kehidupan ketika mereka berdo'a. Do'a adalah dzikir dan ibadah, dalam do'a ada ketenangan jiwa serta obat kesedihan, kebingungan, kegelisahan jiwa. Sebab orang yang berdo'a akan berharap kalau Allah akan mengabulkan do'anya lantaran membenarkan firman Allah Ta aeala (Najati, 2005: 356): "Dan jikalau hamba-hamba-Ku bertanya kepadamu tentang Aku, maka sesungguhnya Aku itu dekat. Aku mengabulkan do'a orang yang berdo'a bila ia memohon kepada-Ku" (QS Al-Baqarah, 2:186).

Arifin (2009: 126) menjelaskan mengenai energi spiritual dari ruhani manusia sebagai kekuatan yang dahsyat dan mendapat dukungan empiris dari dunia Barat. Latihan yang merupakan metode membangkitkan energi spiritual tersebut disebut riyadhoh yang isinya adalah: bersuci dengan wudlu, melakukan shalat, puji-pujian pada Tuhan, permohonan ampun dan do'ado'a yang dipanjatkan dengan tulus sebagaimana non Islam melakukan meditasi: Secara internal proses muhasabah adalah aktivitas nyata dari pelatihan ruhani (riyadhah ruhaniyah) yang sangat jarang dilakukan. Padahal kekuatan ruhani memiliki energi yang dahsyat dan tidak terbatas, tidak seperti kekuatan jasmani yang serba terbatas dan sangat terpengaruh baik oleh situasi maupun kondisi (Arifin, 2009: 126).

Adapun konselor yang dapat diidentifikasi sebagai konselor berorientasi spiritual menurut Boorstein (Lines, 2006: 85) adalah:

"Practitioners working within the science of transpersonal psychology who feel confident and competent to work upon issues of religion and spirituality broadly conceived. They recognise the various dimensions of religion and spirituality and are not perturbed that spiritual aspects of the person are not reducible or contained within conventional psychological constructs. They are quite at home in working with metaphor and symbol, supra-psychology and the transpersonal. Spiritually-inclined therapist recognises and venerates the numinous within human experience and functioning, being neither embarrassed by non-empirical discourse nor afraid to share similar accounts of their own with their clients."

Praktisi yang bekerja dalam ilmu psikologi transpersonal adalah orang yang merasa percaya diri dan kompeten untuk bekerja dengan isu-isu agama dan spiritualitas yang dikonsep secara luas. Mereka mengenal berbagai dimensi agama dan spiritualitas dan tidak bingung bahwa aspek-aspek spiritual dari orang tidak dapat direduksi atau diisi dengan konstruksi psikologis konvensional. Mereka tidak merasa asing dalam bekerja dengan metafora dan simbol, dengan supra-psikologi dan transpersonal.

Terapis spiritual cenderung mengakui dan memuliakan kesucian dalam pengalaman fungsi manusia dan tidak malu dengan wacana non-empiris dan dia juga tidak takut untuk berbagi cerita yang sama tentang mereka sendiri dengan klien mereka.
Adz Dzaky (2004: 299-332)

menyatakan ada beberapa syarat utama yang harus dimiliki oleh konselor Islam, yaitu:

a. Adanya hubungan spiritual yang sangat dekat dengan Rabb-nya yang hal itu diperoleh melalui ketaatannya melaksanakan perintah-Nya dan menjauhi larangannya.

b. Adanya kualitas moral atau akhlak islamiyah yang baik dan benar secara otomatis dari nurani bukan karena rekayasa dan tuntutan profesionalisme. Kualitas moral ini terdiri dari: niat, itikad (keyakinan), amanah, tabligh (menyampaikan), sabar, ikhtiar dan tawakkal, mendo'akan, memelihara kerahasiaan, memelihara pandangan mata. 
c. Adanya pendidikan yang cukup dan menguasai teori-teori konseling Islam maupun umum.

d. Adanya keahlian dan keterampilan dalam melakukan proses konseling dengan metode ilmiah, propetik (kenabian) maupun normatif (Al-Qur'an dan Sunnah). Keterampilan tersebut antara lain: takhalli (pembersihan diri), tahalli (pengisian diri), Tajalli (kelahiran baru), dan pemberdayaan menuju insan kamil.

Nilai-nilai yang dianut manusia salah satunya bersumber dari kepercayaan atau agama. Kepercayaan dan keyakinan manusia tergantung dari pengalaman mereka dalam berinteraksi dengan sesama. Demikian pula aktivitas para konselor dalam hubungan konseling dengan klien mereka. Beberapa penelitian menunjukkan bahwa peran penting para konselor dalam memberikan wawasan tentang nilai-nilai dan apa yang harus dipercayai dan yang tidak perlu dipercayai oleh klien mereka yang akan membentuk konsep diri klien.

\section{Simpulan}

Konseling spiritual merupakan suatu cara berinteraksi antara praktisi konseling dengan mengesampingkan cara lama agar terlibat dalam proses terapi antar manusia, untuk merespon kliennya dengan keterlibatan timbal balik seolah keduanya sedang dalam pengembaraan diri transendens terus menerus dengan memberdayakan dirinya secara individual sebagai manusia. Konseling spiritual adalah proses pemberian bantuan kepada individu agar memiliki kemampuan untuk mengembangkan fitrahnya sebagai makhluk beragama, berperilaku sesuai dengan nilai-nilai agama (berakhlak mulia) dan mengatasi masalah-masalah kehidupan melalui pemahaman, keyakinan dan praktikpraktik ibadah ritual agama yang dianutnya. Tujuan umum konseling spiritual atau keagamaan adalah memfasilitasi dan meningkatkan kemampuan klien untuk mengembangkan kesadaran beragama atau spiritualitasnya dan mengatasi masalahmasalah yang dihadapinya sehingga dapat mencapai kehidupan yang bermakna.

\section{Daftar Pustaka}

Adz-Dzaky \& Bakran. H. (2004). Konseling Dan Psikoterapi Islam. Yogyakarta : Fajar Pustaka Baru.

Ahman \& Kartadinata, S. (2007). Bimbingan dan Konseling Di Sekolah Dasar. Bandung: PT Imperial Sakti Utama.

Ali Aziz, M. (2004). Ilmu Dakwah. Jakarta: Prenada Media.

Ancok, D. (1989). Teknik Penyusunan

Skala Pengukuran. Yogyakarta: PPK UGM.

Arifin, I. Zl. (2009). Bimbingan Penyuluhan Islam. Jakarta: PT Rajagrafindo Persada.

Atkison, R.L. Atkinson, R.C. And Hilgard, E.R. (1996). Pengantar Psikologi. Jakarta: Erlangga.

Bell, A. \& Garrett, P. (1998). Approaches to Media Discourse (First. Published). Malden, Massachusetts: Blackwell Publishers Ltd.

Borg, W.R, Gall, M.D. (2003). Educational Research: An Introduction. London: Longman, Inc.

Burke Mary Thomas, et al. (2005). Religious and spiritual Isssues in Counseling. New York: Bruner-Rutledge Taylor \& Francis Group.

Burns, R. B. (1993). Konsep Diri: Teori, Pengukuran, dan Perkembangan Perilaku. Jakarta: Arcan.

Calhoun, J.F. Acocella, J.R. (1990). Psychology of Adjustment and Human Relationship. New York: McGraw-Hill, Inc. 
Colleta, V.P, Phillips, J.A \& Steinert, J.J. (2007). Interpreting Force Concept Inventory Scores: Normalized-Gain and SAT Scores. The American Physical Society 3, 010106. 1-5.

Corey, G. (1997). Teori Dan Praktek Konseling Dan Psikoterapi. Bandung: PT Eresco.

Kusnawan, A. (2004). Komunikasi Penyiaran Islam. Bandung : Merah Press

Lines, D. (2006). Sprituality in Counseling and Psychotherapy. London: Sage Publications.

Makhdlori, M. (2007). Keajaiban membaca Al-Qur'an : mengurangi kemukjizatan fadhilah membaca AlQur'an terhadap kesuksesan anda. Yogyakarta: Diva Press.

Miller, G. (2003). Incorporating Spirituality in Counseling and Psychotherapy. New Jersey: John Wiley and Sons, INC.

Munir, M. \& Ilaihi, W. (2006). Manajemen Dakwah. Jakarta: Prenada Media Group.

Najati, M.U. (2005). Ilmu Jiwa dalam Al Qur'an. Jakarta: Pustaka Azzam. 